\title{
Reformist Hagiography: The Life of St Roding of Beaulieu and the Struggle for Power in Early Eleventh-Century Lotharingia
}

\section{Koen Vanheule}

Sint-Pietersnieuwstraat 35, 9000 Ghent, Belgium.

Tel. +32479532649

E-mail: koen.vanheule@ugent.be

Koen Vanheule is a $\mathrm{PhD}$ student at Ghent University. He is currently working on a project regarding monastic leadership and reform in eleventh-century Lotharingia, with professors S. Vanderputten (Ghent University) and B. Meijns (Catholic University of Leuven) as his supervisors.

This research is supported by the Flemish Research Foundation (FWO) under Grant $\mathrm{B} / 11721 / 02$. 


\title{
Reformist Hagiography: The Life of St Roding of Beaulieu and the Struggle for Power in Early Eleventh-Century Lotharingia
}

\begin{abstract}
This paper explores an example of 'reformist' hagiographic production in early eleventh-century Lotharingia by focusing on the Life of St Roding of Beaulieu, a small monastery in the diocese of Verdun. Until recently, this text was interpreted exclusively in terms of the scant information it provides on this institution's early medieval history and in terms of its ideological message regarding monastic discipline and leadership. By integrating the redaction of this text into the thencurrent regional geography and political context, this paper proposes a new approach to its interpretation and to the understanding of Beaulieu's 'monastic reform' in general. Close analysis of the narrative reveals that its redaction was inspired by specific issues relating to local and regional politics in the mid-1010s, and that parts of the institution's recent history were allegorically veiled behind the portrayal of Roding. However, rapid changes in power relationships rendered those aspects of the text outdated within a few years. This raises significant questions regarding the long-term relevance of such hidden stories and the degree to which their various ideological, political and other messages remained accessible to medieval audiences.
\end{abstract}

Keywords: hagiography; monastic reform; nobility; eleventh century; Lotharingia; Beaulieu; Abbot Richard of Saint-Vanne; Poppo of Stavelot

During the first two decades of the eleventh century, war raged in Upper Lotharingia. The unity among the descendants of Count Palatine Wigeric of Lotharingia (d. 915/16) had collapsed. ${ }^{1}$ In particular, the sons and daughters of Count Siegfried of Luxembourg

${ }^{1}$ Wigeric of Lotharingia was the first husband of Kunigunde, a descendant of the Frankish king Charles the Bald (843-877). Wigeric and Kunigunde founded the powerful house of 'Ardennes', and three of their children became the ancestors of the families that dominated Lotharingian politics during the tenth and eleventh centuries. Their son Gozlin's (911942/42) offspring became the counts of Verdun, their son Frederic became the first count of Bar and the duke of Upper Lotharingia, and their son Siegfried became the first count of Luxembourg. These families are known as the 'Ardennes-Verdun', 'Ardennes-Bar' and 
proved hungry for more power. They already counted the German Empress Kunigunde and the Bavarian Duke Henry V amongst their siblings when Thierry of Luxembourg usurped the episcopal see of Metz in 1005-1006, thereby breaking the pact of trust with his cousins from the family of Bar. ${ }^{2}$ Even though these actions disturbed the balance of power in the region, it was only after his brother Adalbero of Luxembourg illicitly arranged to be elected bishop of Trier in 1008 that Emperor Henry II deployed his army to Trier and Metz. ${ }^{3}$ This marked the beginning of a fierce regional war that lasted almost a decade and involved many other regional magnates, including the dukes of Upper and Lower Lotharingia, the count of Metz, the count palatine of Lotharingia, the future Emperor Conrad II and the bishops of Verdun and Toul.

As this regional conflict was unfolding, in 1015 or early 1016, Bishop Haimo of Verdun (988-1024) entrusted the abbacy of the remote monastery of Beaulieu-inArgonne to Richard of Saint-Vanne, who is traditionally represented as one of the principal figureheads of monastic reform in early eleventh-century Lotharingia. ${ }^{4}$ Shortly

'Ardennes-Luxembourg' families, although in this article, the prefix 'Ardennes' will be omitted. Heinz Renn, Das erste Luxemburger Grafenhaus (963-1136) (Bonn, 1941), 227; Michel Parisse, 'Généalogie de la maison d'Ardenne', Publications de la Section historique de l'Institut grand-ducal de Luxembourg 95 (1981), 12-41; Jean-Pol Evrard, 'Les comtes de Verdun aux $\mathrm{X}^{\mathrm{e}}$ et $\mathrm{XI}^{\mathrm{e}}$ siècles', Publications de la Section historique de l'Institut grand-ducal de Luxembourg 95 (1981), 155.

2 Markus Twellenkamp, 'Das Haus der Luxemburger', in Die Salier und das Reich, vol. 1, ed. Stefan Weinfurter et al. (Sigmaringen, 1991), 480. The former bishop of Metz, Adalbero II, brother of Thierry I of Bar, had arranged that Thierry I's son, Adalbero, would succeed him as bishop of Metz. Due to the latter's minority when Adalbero II died in 1005, Thierry of Luxembourg became regent of Metz's bishopric. He then chased the minor Adalbero out of Metz, thereby claiming the episcopal office for himself. See also figure 2; regarding the dating of this event, see note 97.

${ }^{3}$ Franz-Reiner Erkens, 'Fürstliche Opposition in ottonisch-salischer Zeit', Archiv für Kulturgeschichte 64 (1982), 349-51.

${ }^{4}$ For the historiography on Richard of Saint-Vanne, see Steven Vanderputten, Imagining Religious Leadership in the Middle Ages: Richard of Saint-Vanne and the Politics of Reform (Ithaca, NY, 2015), 5-6. Vanderputten recently proposed an alternative reading of Richard's interventions, criticizing the concept of 'reform', see Steven Vanderputten, 
thereafter, Richard appointed Poppo, his former prior in Saint-Vaast, to take charge of this small institution's daily government. Due to Richard's present-day reputation, their intervention in Beaulieu has generally been called a 'monastic reform'. ${ }^{5}$ However, every available source either from this period or postdating it fails to inform us about any of their supposedly reformist activities in this institution. Nevertheless, several elements suggest that Haimo's appointment of Richard may hide a rather more interesting story than has been assumed. For example, there is the question of why Bishop Haimo of Verdun burdened Richard with this poor and relatively isolated institution, while the latter was already heavily preoccupied with the government of several major monasteries, including Saint-Vanne (Verdun) and Saint-Vaast (Arras). ${ }^{6}$ This becomes all the more intriguing knowing that Richard's appointments, such as in the Flemish Saint-Vaast abbey, often had distinctly political motivations. ${ }^{7}$ Also Richard's choice to delegate the daily governance of Beaulieu to his associate Poppo may seem odd knowing that Poppo had until just recently occupied the high-profile position of prior of Saint-Vaast. In any case, Poppo's years of service in Beaulieu must have impressed the German Emperor Henry II, for in 1020, Henry entrusted Poppo with the abbacy of the imperial monastery of Stavelot-Malmedy. ${ }^{8}$ Meanwhile, the only trace of Richard's direct involvement with the monastery that has been preserved is the Vita Rodingi, a short biography of Beaulieu's seventh-century founder Roding, which Richard either wrote or whose redaction he at least commissioned. ${ }^{9}$

Monastic Reform as Process: Realities and Representations in Medieval Flanders, 9001100 (Ithaca, NY, 2013), 79-101.

${ }^{5}$ For example, Dorothee Schäfer, Studien zu Poppo von Stablo und den Klosterreformen im 11. Jahrhundert (München, 1991), 34-5.

${ }^{6}$ Vanderputten, Imagining, 10. The monasteries of Saint-Amand (1013), Florennes (c. 10101015) and Hautmont (c. 1015) were also under his care.

${ }^{7}$ Vanderputten, Monastic Reform, 83-4.

${ }^{8}$ Vanderputten, Monastic Reform, 90.

${ }^{9}$ The Vita Rodingi has most recently been edited by Vanderputten, Imagining, 262-83 [referred to hereafter as Vita Rodingi], who also provided a translation in English. Richard's authorship of this Vita is claimed by his anonymous twelfth-century biographer and has been acknowledged by most modern scholars, see Vita Richardi, ed. Wattenbach (MGH SS, 11, Hannover, 1854), c. 12, 286; Vanderputten, Imagining, 62, 262. 
Upon first inspection, this Vita seems a fairly trivial example of hagiographical writing, lacking ambition in both content and style. Adding to this the text's limited distribution, one would be tempted to suppose it was strictly intended to promote Roding's cult locally. ${ }^{10}$ However, knowing that some of Richard's other writings contain several explicit and implicit layers, both political and spiritual, it is likely that the Vita Rodingi likewise represents more than just a one-dimensional, and largely fictitious, saint's story. ${ }^{11}$ Recently, Anne Wagner suggested that this Vita legitimized Richard's ideas on eremitism, while Steven Vanderputten has demonstrated how Richard used this text to propagate his view of the ideal religious leader, identifying himself with his subject. ${ }^{12}$ Furthermore, Wolfgang Haubrichs has argued that the various descriptions of Roding's miracles served to secure the freehold of Beaulieu, a purpose not alien to the hagiographical genre. ${ }^{13}$

This paper will expand upon these recent arguments, contending that the Vita Rodingi actually offers us the key to understanding the rationale behind Richard and Poppo's 'reform' of Beaulieu. When redacting Roding's life story, Richard took inspiration from the institution's recent history, and the tale of a local struggle for control between the family of Bar, the bishop of Verdun and the abbey itself was

${ }^{10}$ Vanderputten, Imagining, 262-3. Only one copy of the Vita has been preserved, written around 1100, and it currently resides in Châlons-en-Champagne, BM 57, at fols. 53v-59r.

${ }^{11}$ As an example, see Richard's circular letter from 1011/12, see David C. Van Meter, 'Count Baldwin IV, Richard of Saint-Vanne and the Inception of Monastic Reform in EleventhCentury Flanders', Revue Bénédictine 107 (1997), 142-3; Vanderputten, Monastic Reform, 86-90. As far as is known, the Vita Rodingi is one of only two hagiographic works written by Richard, the other being the Vita Sancti Vitoni. Apart from these two texts, Richard did not actively initiate or inspire any other hagiographic undertakings, see Vanderputten, Imagining, 62; Vanderputten, Monastic Reform, 133-4.

12 Anne Wagner, 'La vie de Saint Rouin', in Beaulieu-en-Argonne. Abbaye en pays frontière, ed. Noëlle Cazin, Marie-Hélène Colin and Jackie Lusse (Bar-le-Duc, 2004), 37-8; Vanderputten, Imagining, 63-8.

${ }^{13}$ Wolfgang Haubrichs, Die Tholeyer Abtslisten des Mittelalters (Saarbrük, 1986), 100. On the functionality of hagiography, see Guy Philippart, 'L'hagiographie: histoire sainte des "amis de Dieu", in Hagiographies. Histoire internationale de la littérature latine et vernaculaire en Occident des origines à 1550, ed. Guy Philippart (Turnhout, 2006), 28. 
allegorically encrypted in this text. By unveiling this anecdote of the early eleventhcentury history of Beaulieu, previously considered lost, it becomes clear that Richard and Poppo's intervention can only be fully be understood by taking the regional political context into account. Finally, this interpretation renders intelligible not only Richard's efforts in writing this text, but also the text's attenuated dissemination.

\section{Beaulieu as Medieval Borderland}

Before uncovering the story hidden in the Vita, a short excursion into Beaulieu's history and topography is indispensable. The monastery of Beaulieu was located in the Eastern Frankish duchy of Upper Lotharingia, in the borderland between the counties of Verdun and Bar, at an almost equal distance from the cities of Bar-le-Duc and Verdun (c. 30-35 $\mathrm{km}$ ), near the border between the bishoprics of Verdun and Toul. ${ }^{14}$ It was situated on the western fringes of the Upper Lotharingian border, merely a few kilometres from the Western Frankish kingdom. ${ }^{15}$ However, it is not so much its position on the map but, rather, the local geography that makes clear the strategic value of its location. The monastery's peripheral position at the margins of the mountainous region of Argonne, on top of a hill, affords an excellent view over the plains stretching from Verdun, in the north-east, to Éclaires, situated south-west of the abbey, with Bar-le-Duc being more or less in the middle of its vista. ${ }^{16}$ The greater part of the border region between Eastern and Western Francia is to the monastery's back, largely hidden behind the Argonne's other hills. Consequently, Beaulieu was perfectly located for surveying the southern border of the county and the bishopric of Verdun as well as most of the county of Bar, which was situated in the bishopric of Toul.

${ }^{14}$ Laurent-Henri Cottineau, Répertoire topo-bibliographique des abbayes et prieurés, vol. 1 (Mâcon, 1935), 302-3.

${ }^{15}$ On the issue of the borderline between Eastern and Western Francia, see Michel Bur, 'La frontier entre la Champagne et la Lorraine du milieu du $\mathrm{X}^{\mathrm{e}}$ à la fin du XII ${ }^{\mathrm{e}}$ siècle', in: Francia 4 (1976), 237-54. Beaulieu was situated a few kilometres east of the Astenois, which belonged to the Western Frankish kingdom.

${ }^{16}$ See figure 1. 
Founded in the seventh century, Beaulieu was called 'Waslogium' before its change of name sometime between 1015 and $1020 .{ }^{17}$ Its pre-1100 history remains largely obscure, with just a few fragmentary mentions in the sources. As far as we can reconstruct, the abbey remained under Western Frankish royal protection until at least 870. ${ }^{18}$ Nonetheless, the Gesta Virdunensium, written in 916-925, claims that somewhere in the early eighth century Beaulieu had once been entrusted to Verdun's bishop, only to be usurped again by Charles Martel a few decennia later. ${ }^{19}$ According to Hirschmann, it was during the period 893-923 that Beaulieu finally became an episcopal monastery, when Bishop Dado of Verdun (880-923) seized the abbey from Western Frankish royal authority. ${ }^{20}$ However, this is mentioned nowhere in the Gesta Virdunensium. Since Dado of Verdun had commissioned the redaction of this Gesta, one would expect references in the text to his own claim over Beaulieu. ${ }^{21}$ Of course, it is possible that Dado had only taken possession of Beaulieu shortly after the Gesta's redaction, but the lack of references may also mean that Hirschmann's hypothesis is wrong, and that Beaulieu remained in Western Frankish royal possession during the first half of the tenth century. ${ }^{22}$ In any case, Haimo's initiative to send Richard to Beaulieu

${ }^{17}$ On Beaulieu's early history, see Frank G. Hirschmann, 'L'abbaye de Beaulieu des origines au $\mathrm{XI}^{\mathrm{e}}$ siècle', in Beaulieu (see note 12), 11-4; Wolfgang Haubrichs, 'Die Urkunde Pippins des Mittleren und Plectruds für Saint-Vanne in Verdun (702)', Francia 13 (1985), 37-8.

${ }^{18}$ In the Meerssen treaty from 870, 'Wasloi' is mentioned as one of Charles the Bold's royal monasteries, see Annales de Saint-Bertin, ed. Félix Grat, Jeanne Vielliard and Suzanne Clémencet (Paris, 1964), 174. Also Haubrichs, 'Urkunde', 9 note 63.

${ }^{19}$ Gesta episcoporum Virdunensium, ed. Georgio Waitz (Monumenta Germaniae Historica (MGH), Scriptores (SS), 4, Hannover, 1841), c. 9, 43 and c. 13, 44 [referred to hereafter as Gesta, ed. Waitz]. The Gesta incorrectly dated the Frankish re-usurpation of Beaulieu to Charlemagne's time, see Haubrichs, Abtslisten, 109.

${ }^{20}$ Hirschmann, 'L'abbaye', 17. Hirschmann based his argument upon records of a procession in Jouy-en-Argonne, in the bishopric of Verdun, in which St Roding participated for a first time in 923.

${ }^{21}$ Frank G. Hirschmann, Verdun im hohen Mittelalter (Trier, 1996), 49.

${ }^{22}$ In the first scenario, Haimo possibly took advantage of the struggle for power in Western Francia between the Robertians and the Carolingian kings in 922, which may have created a power vacuum in peripheral institutions such as Beaulieu. See Karl Ferdinand Werner, 
suggests that by 1015/16, Beaulieu had become an episcopal Eigenkloster, or at least that the bishop of Verdun was claiming a certain degree of control over this monastery, in this case the right to appoint an abbot of his own liking. Since a charter from 1172 records that Bishop Adalbero of Verdun donated Beaulieu to the counts of Bar, it can be argued that Beaulieu had remained in Verdun's episcopal possession until the later twelfth century. ${ }^{23}$

Equally important for our study, but even more challenging to uncover, is the question of in whose county the abbey was situated at the time of Richard's nomination. Due to Beaulieu's location, this was most likely in the Upper Lotharingian counties of either Bar or Verdun. Even though a charter from 1065-1069, in which Godfrey III of Verdun regulates the advocate's rights in the bishopric of Verdun, indicates that Beaulieu belonged to the county of Verdun at that time, this does not necessarily mean that it belonged to this county in the preceding and subsequent decades, as will be discussed below. ${ }^{24}$ However, as a precise reconstruction of the official border - if there even was one - dividing the counties of Bar and Verdun is rather impossible, it remains difficult to situate Beaulieu in the sphere of influence of one or the other. ${ }^{25}$ Nonetheless, an attempt at approximating it allows for some interesting observations. Extant sources indicate that the family of Bar's possessions south of Beaulieu included Vaubécourt (c. $12 \mathrm{~km}$ to the south) and Courcelles-sur-Aire (c. $18 \mathrm{~km}$ to the south-east), to be found in

'Les Robertiens', in Le roi de France et son royaume autour de l'an mil, ed. Michel Parisse and Xavier Barral i Altet (Paris, 1992), 22-4.

${ }^{23}$ P. Auguste Lemaire, Recherches historiques sur l'abbaye et le Comté de Beaulieu-enArgonne (Bar-le-Duc, 1873), 177-8.

${ }^{24}$ The 1065-1069 charter has been edited in Hermann Bloch, 'Die älteren Urkunden des

Klosters S. Vanne zu Verdun, schluss', Jahrbuch der Gesellschaft für lothringische

Geschichte und Altertumskunde 14 (1902), nr. 54, 77-80. For its dating, see Georges

Despy, 'Les actes des ducs de Basse-Lotharingie du XI ${ }^{\mathrm{e}}$ siècle', Publications de la section historique de l'Institut Grand-Ducal de Luxembourg 95 (1981), 68.

${ }^{25}$ According to Bur, the delineation of high medieval borders between pagi was known precisely by contemporaries, but, due to lack of sources, can -at its best- only be approximately reconstructed. Bur, 'La frontière', 238, 253-4. 
charters from 1006 and c. 984 , respectively. ${ }^{26}$ When we compare this to Haubrichs' reconstruction of the region controlled by the Beaulieu abbey, we can see that the count of Bar's range of power not only touched this region but even overlapped it in Vaubécourt. ${ }^{27}$ When subsequently looking at Evrard's reconstruction of the county of Verdun's southernmost border in the middle of the eleventh century, which equated with Verdun's episcopal borders, we can also see a partial overlap with certain regions controlled by the counts of Bar a few decennia earlier, including Vaubécourt. ${ }^{28}$ In any case, this overlap illustrates that it is a rather impossible task to try to discover which lay lord may have laid claim to some degree of territorial control over this monastery based on a demarcation of borders.

However, the history of how the counts of Bar had obtained their possessions proves to be more illuminating. When the first count of Bar, Frederic I (d. 978), married Beatrix of France, the eldest daughter of Hugh the Great, in 954, he received as a dowry all royal rights over Hugh's properties situated in the Lorraine region, including the abbeys of Saint-Mihiel, Moyenmoutier and Saint-Dié and the region around Bar-leDuc. ${ }^{29}$ Being the son of the former Western Frankish king Robert, and as duke of the Franks and regent of the Western Frankish King Lothaire, Hugh the Great himself had probably obtained these possessions around 930 from the prestigious monastery of Saint-Denis, near Paris, which administered the Western Frankish royal domains in the

${ }^{26}$ The 1006 charter has been edited in André Lesort, Chronique et chartes de l'abbaye de SaintMihiel (Paris, 1909-1912), 135-7, nr. 32. For the charter of c. 984, see Benoit Picard, Histoire ecclésiastique et politique de la ville et diocèse de Toul (Toul, 1707), 336-7. Even though this charter mentions how Courcelles-sur-Aire was ceded to the bishop of Toul, the count of Bar retook possession of this village in the beginning of the eleventh century, see further, note 66. For an overview of the domains controlled by the counts of Bar, see Georges Poull, La maison souveraine et ducale de Bar (Nancy, 1994), 7; Picard, Histoire, 98.

\footnotetext{
${ }^{27}$ Haubrichs, Abtslisten, 110.

${ }^{28}$ Evrard, 'Les comtes', 165-6. Following this border, Courcelles-sur-Aire and Vaubécourt were also situated in the county of Verdun.

${ }^{29}$ Poull, La maison, 8-12.
} 
Lorraine region. ${ }^{30}$ During the second half of the tenth century, the Bar family expanded their territories by usurpation or trade, for example by abandoning Moyenmoutier and Saint-Dié to the bishop of Toul in 984 in exchange for several mansi and villages. ${ }^{31}$ Thus, by the time of Richard's appointment in Beaulieu in 1015, Count Thierry I of Bar exercised control over a large area in the Eastern Frankish duchy of Lotharingia, whose core consisted of former Western Frankish royal possessions. Knowing that the abbey of Beaulieu was still under Western Frankish royal protection in 870, and given Beaulieu's location near Hugh the Great's ascertainable possessions in Lorraine, it is not unthinkable that Hugh the Great had claimed some degree of ownership over Beaulieu as well. Consequently, if Bishop Dado of Verdun had indeed usurped the abbey from Western Frankish royal ownership sometime in the 920s, it was Hugh the Great, and later his daughter Beatrix and her husband Frederic I of Bar, who were the most likely persons to contest Verdun's episcopal claim over Beaulieu. If this scenario is correct, then by the time Bishop Haimo appointed Richard of Saint-Vanne as abbot in Beaulieu, Count Thierry I of Bar may have believed that he had inherited some degree of worldly control over this institution. Even if this was not the case, then Beaulieu was certainly one of his key targets in his expansion northward. After all, considering the strategic location of Beaulieu and its position overlooking the county of Bar, it is not at all unthinkable that Thierry I of Bar desired to secure the northern and western borders of his county by at least trying to have an abbot of his own liking nominated in Beaulieu, instead of allowing this right to be in the hands of the neighbouring bishop of Verdun, who also held supreme worldly power in the county of Verdun. ${ }^{32}$

${ }^{30}$ Michel Parisse, 'Saint Denis et ses biens en Lorraine et en Alsace', Bulletin philologique et historique du comité des travaux historiques et scientifiques 1 (1967), 234-9, 244-8. Saint-Denis had acquired these properties from King Pepin, Charles Martel's son, around 755 , thus during a time in which Beaulieu belonged to the Frankish kings.

${ }^{31}$ Marcel Grosdidier de Matons, Le comté de Bar des origines au traité de Bruges (vers 9501301) (Paris, 1922), 58-9, 520-1.

${ }^{32}$ The counts of Verdun received their authority from the bishops of Verdun, who were the 'true rulers' of the county of Verdun, see Evrard, 'Les comtes', 169-70. For the issue of the nobility's control over abbatial elections, see Hubertus Seibert, Abtserhebungen zwischen Rechtsnorm und Rechtswirklichkeit (Mainz, 1995), 378-82. 
Additional sources from subsequent years support this hypothesis, such as the aforementioned charter from 1065-1069, which states that Beaulieu belonged to Godfrey III of Verdun's county. ${ }^{33}$ During those years, Godfrey III was married to Beatrix of Bar, granddaughter of Thierry I of Bar, who also appears in the charter. ${ }^{34}$ When the house of Bar became extinct in the male line with the death of young Frederic III of Bar in 1033, his estate was divided between his sisters Beatrix and Sophia. ${ }^{35}$ While Sophia received the abbey of Saint-Mihiel and the fortress of Bar, Beatrix inherited the northern parts. ${ }^{36}$ This principally encompassed the family possessions north-west of the county of Verdun, although it is not inconceivable that it also covered the domains near the county of Verdun's southern border, including Beaulieu. After the death of Beatrix's first husband, Boniface III of Tuscany, she married Godfrey III of Verdun in 1054, who took up the management of her hereditary Lotharingian possessions. ${ }^{37}$ This explains why Beaulieu appeared as Godfrey III's territory in the later 1060s, as well as the overlap between the mid-eleventh-century southern border of the county of Verdun and the early eleventh-century northern possessions of the family of Bar outlined above.

Also, later developments reveal that the Bar family had an ongoing interest in Beaulieu. After Beatrix's death, her properties in Lotharingia and Italy were passed on to her only child from her first marriage, Mathilda of Canossa. As the latter was married to Godfrey the Hunchback, son of Godfrey III of Verdun by his first marriage, the northern parts of the family of Bar's patrimony remained under control of the Verdun family. However, shortly before Mathilda's death in 1115, she donated all of her and her husband's inheritance in Lotharingia to the bishops of Verdun, Liège and Metz. ${ }^{38}$ This was heavily contested by Reginald I, grandson of Sophia of Bar and count of Bar

\footnotetext{
${ }^{33}$ See note 24 above.

${ }^{34}$ Bloch, 'Urkunden, schluss', 79.

${ }^{35}$ Poull, La maison, 23-5; Eduard Hlawitschka, 'Zur Herkunft und zum Namen Sophies von Bar und Mousson', Zeitschrift für die Geschichte des Oberrheins 152 (2004), 23-52.

${ }^{36}$ Poull, La maison, 32.

${ }^{37}$ Lampert of Hersfeld, Annales, ed. Oswaldus Holder-Egger (MGH, SS rerum Germanicarum in usum scholarum separatim editi (SS rer. Germ.), 38, Hannover and Leipzig, 1894), 64.

${ }^{38}$ Poull, La maison, 92.
} 
from 1105-1149, who invested a great deal of time and effort in recovering these possessions, as well as in conquering the entire county of Verdun. ${ }^{39}$ Reginald only gave up these attempts in 1134, when the bishop of Verdun gave him the fortifications of Clermont-en-Argonne, Hans and Vienne as compensation. ${ }^{40}$ The location of these three fortresses is of particular interest for our case, as they are situated on the western border of the bishopric of Verdun, a few kilometres north and north-west of Beaulieu. This means that Beaulieu, from 1134 on, was situated in the heartland of the county of Bar and that the bishop of Verdun had come to recognize the de facto control by the Bar family over the regions surrounding the abbey. Nevertheless, it was only in the 1170s that the bishop of Verdun officially handed over his rights over Beaulieu to Henry I, count of Bar. ${ }^{41}$ Consequently, this transfer probably marked the end of more than 200 years of struggle between the house of Bar and the bishops of Verdun for lordship over this monastery.

\section{The Vita Rodingi's Hidden Story of a Local Conflict}

There are several indications that this local struggle for control over Beaulieu's strategic location was not just the backdrop of the Vita Rodingi's redaction but, rather, one of Richard's main sources of inspiration. However, we first need to take a closer look at the text's hidden layers. The Life of Roding is a fairly simple and straightforward story, consisting of only 21 chapters. It can be divided roughly into four parts. The first five chapters deal with Roding's Irish origins, his career as monk and abbot in Tholey, and his foundation of Beaulieu with the bishop of Verdun's consent. The second part, consisting of chapters 6 through 12, deals with a conflict between Roding and Austresius, a local nobleman. In this portion of the text, Roding performs a number of miracles in the surroundings of Beaulieu, after which he makes peace with Austresius. In chapters 13 through 16, the third part, Beaulieu increases its prestige, with Roding

\footnotetext{
${ }^{39}$ Idem.
}

${ }^{40}$ Alberic of Trois-Fontaines, Chronicon, ed. Paulus Scheffer-Boichorst et al. (MGH, SS, 23, Hannover, 1874), anno 1131, 830; Poull, La maison, 92.

${ }^{41}$ This charter has been edited in Lemaire, Recherches, 177-8. Lemaire situates it c. 1175, while Grosdidier de Matons argued that it cannot be older than 1178, Marcel Grosdidier de Matons, Catalogue des actes de comtes de Bar de 1022 à 1239 (Paris, 1922), 52, nr. 116. 
stealing some relics from St Mauritius, after which he also received a privilege from the Frankish king. Finally, chapters 17 through 22 deal with Roding's urge to lead an eremitic life, his interest in astrology, and his death and burial.

As mentioned, Vanderputten has already demonstrated how Richard used the depiction of Roding to assert his own identity and ideas regarding abbatial leadership, which becomes most apparent in the first and last parts of the Vita. ${ }^{42}$ Roding's early career in Tholey also relates to Richard's personal experience, for Abbot Eberwin of Tholey was one of Richard's closer friends. ${ }^{43}$ Even Richard's description of Roding's Irish origins probably refers to Richard's own social environment, since the 'real' Roding most likely originated from Austrasia. ${ }^{44}$

My focus here will be mainly on the two middle parts of the Vita, which deal with the local conflict and the expansion of Beaulieu. Traditionally, these chapters have been regarded as a 'proto-cartularium', meaning an attempt to define Beaulieu's earliest possessions, rights and liberties. ${ }^{45}$ However, such a hypothesis is undermined by the odd choice of properties mentioned in the Vita Rodingi. According to Haubrichs, the five place names mentioned - Austresii Curtis (chapter 6), Riessonnis (chapter 8), Argisivilla (chapter 9), Bonna (chapter 12) and Ermeriacam (chapter 16) - refer respectively to Autrécourt-sur-aire, Resson, Auzéville, Bonne and Evres-en-Argonne, all located within $30 \mathrm{~km}$ of the monastery. ${ }^{46}$ Wagner then suggested that 'Argisivilla' is

${ }^{42}$ Vanderputten, Imagining, 69-73; Wagner, 'Vie de Saint Rouin', 25-7, 35-7. See also Steven Vanderputten, 'Death as a Symbolic Arena: Abbatial Leadership, Episcopal Authority and the "Ostentatious Death" of Richard of Saint-Vanne (d. 1046)', Viator. Journal of Medieval and Renaissance Studies 44 (2013), 38-42.

${ }^{43}$ Haubrichs, Abtslisten, 166-72; Vanderputten, Imagining, 69-71. Haubrichs argued that Roding might indeed have been abbot of Tholey. Haubrichs, Abtslisten, 113-4.

${ }^{44}$ Vanderputten, Imagining, 64. For example, Fingen, Richard's predecessor in Saint-Vanne, originated from Ireland. Haubrichs suggested that Roding's presumed Irish origins stems from an oral tradition. According to Wagner, this was due to the standing of Irish monks within Lotharingian monasticism. Haubrichs, Abtslisten, 112, 114-6; Wagner, 'Vie de Saint Rouin', 27-8.

${ }^{45}$ Haubrichs, Abtslisten, 99-100; Hirschmann, 'L'abbaye', 13; Wagner, 'Vie de Saint Rouin', 24 note $11,30-5$.

${ }^{46}$ Haubrichs, Abtslisten, 100, 108-9. 
more likely to be Hargeville, as will be discussed below. ${ }^{47}$ Claiming that these possessions constituted Beaulieu's original domains no longer proves tenable when taking into account other reconstructions of Beaulieu's initial territory. Based upon a charter of Pepin Herstal from 702, Haubrichs demonstrated that the abbey actually controlled an unbroken area stretching to the south (Foucaucourt, Evres, PretzSommaisne, Triaucourt, Vaubécourt, Charmontois-l'Abbé, Senard, Eclaires, Gumont, Grigny, Aubercy, Le Chemin) and to the south-east (Fleury-sur-Aire, Lavoye, Froidos). ${ }^{48}$ Indeed, comparing this region with the places in the Vita Rodingi, we find that Resson and Auzéville/Hargeville are extraneous to its delineation, while Autrécourt was on its eastern border. Moreover, 'Bonna', which, according to Haubrichs, would refer to a brook near Autrécourt, can also hardly be considered one of the abbey's most important possessions. ${ }^{49}$ Only Richard's mention of Evres (Ermeriacam) seems to make sense, as this was the most important centre of Beaulieu's domains, and was still acting as the abbatial court and marketplace in the thirteenth century. ${ }^{50}$ Consequently, we can argue that Richard was not trying to reconstruct the abbey's primary possessions when writing these chapters but, rather, must have had other intentions in mind. ${ }^{51}$ [Figure 1 near here]

Let us begin with the story about the conflict between Roding and the nobleman, Austresius, which occupies no fewer than four chapters. ${ }^{52}$ They recount how Austresius, who resided at 'Austresii curtis', threatened and evicted Roding and his followers from the forests around Beaulieu, which belonged to Austresius by hereditary right (ch. 6). Thereafter, Roding left for Rome to obtain papal approval for his plans, while Austresius received heavenly punishment, becoming ill and losing his children, animals

\footnotetext{
${ }^{47}$ Wagner, 'Vie de Saint Rouin', 31 note 46.

48 Haubrichs, 'Urkunde', 4, 8-11, 37-9. This charter has been preserved in a twelfth-century cartulary from Saint-Vanne and is edited in Hermann Bloch, 'Die älteren Urkunden des Klosters S. Vanne zu Verdun, vol. II', Jahrbuch der Gesellschaft für lothringische Geschichte und Altertumskunde, 10 (1898), 377-8.

${ }^{49}$ Haubrichs, Abtslisten, 100 note 443.

${ }^{50}$ Hirschmann, 'L'abbaye', 13.

${ }^{51}$ Wagner already proposed that these names referred to places contested during the Vita's redaction, see Wagner, 'Vie de Saint Rouin', 32.

${ }^{52}$ Vita Rodingi, c. 6-7, 267-8, c. 11-12, 271-2.
} 
and a great number of his servants (ch. 7). In the next few chapters, Roding performed several miracles, after which Austresius changed his mind and humbly asked the holy man to heal him (ch. 11). Finally, out of gratitude, Austresius donated the forests around Beaulieu to Roding, to be held for all eternity (ch. 12).

So far, this story has been considered a hagiographic topos, serving to prove that Beaulieu possessed Autrécourt. However, nowhere in the Vita is it mentioned that Austresius donated his own 'curtis' to Roding, only the forests around Beaulieu. Consequently, this means that the text never asserts that Beaulieu owned 'Austresius curtis' itself. Moreover, there are indications that the church of Autrécourt never actually belonged to Beaulieu but, instead, belonged to the diocese of Verdun. ${ }^{53}$ Furthermore, the orthographic origin of 'Autrécourt' is rather difficult to reconcile with Richard's appellation 'Austresius curtis'. The earliest ascertainable appellation of Autrécourt appears in a charter from 1069, where it is called 'Austraudicurtis', which derives from the Germanic 'Austr(o)aldus cortem', or place of Austroaldus. ${ }^{54}$ Indeed, 'Austresius curtis' is a rather creative corruption of the name 'Astraudi curtis'. Haubrichs suggested that this is a folk-etymological degeneration of the name 'Austroald' to 'Austrasius' and subsequently to 'Austresius'. ${ }^{55}$ However, since it was not Richard's intention to secure the abbey's alleged possession of Autrécourt through the story of Austresius, or even to refer to this village, Haubrich's hypothesis no longer

${ }^{53}$ Auguste Longnon and Victor Carrière, Pouillés de la province de Trèves (Paris, 1915), 369. Haubrichs resolved this by proposing that Roding's possessions had been transferred to the bishop of Verdun, see Haubrichs, Abtslisten, 110 note 473.

${ }^{54}$ Ernest Nègre, Toponymie générale de la France (Genève, 1990), 882, nr. 15549. The charter from 1069 has been edited electronically in Cédric Giraud, Jean-Baptiste Renault and Benoît-Michel Tock, eds., Chartes originales antérieures à 1121 conservées en France (Nancy, 2010), nr. 1927, http://www.cn-telma.fr/originaux/charte1927/ (accessed October $8,2014)$. Nègre also identified the name 'Authéricurtis' in a charter from 904 as Autrécourt, although this actually refers to Audricourt, a village which was located in the district Vitry-le-François. See Warin, Cartulaire du chapitre de l'église cathédrale de Châlons-sur-Marne (Paris, 1897), 58; Philippe M. Lauer, Recueil des actes de Charles III le simple (Paris, 1949), 105-6, nr. 48.

${ }^{55}$ Haubrichs, Abtslisten, 100 note 440. 
seems tenable. Nevertheless, the question remains why Richard chose this specific name for the villainous nobleman.

In order to find an answer, we must try thinking like Richard, imagining that his eleventh-century audience understood the underlying meaning of this name. Haubrichs' suggestion that 'Austresius' derived from 'Austrasius' was probably correct. But, rather than referring to 'Austroaldus', this name is actually very reminiscent of the former region Austrasius and thus might be considered its personification. During the seventh century, when Roding lived, the name 'Austrasius' was used to denote the north-eastern part of the Merovingian kingdom. In present day terms, this covers the eastern parts of France, the Belgian territory east of the Scheldt river, southern parts of the Netherlands and some western parts of Germany, with Metz as its capital. During Richard's time, this region roughly corresponded with the duchy of Lotharingia, divided since 959 or 977 into a northern and southern part, respectively known as Lower and Upper Lotharingia. ${ }^{56}$ In 1015, when Richard became abbot of Beaulieu, the duke of Lower Lotharingia was Count Godfrey II of Verdun, while the duke of Upper Lotharingia was Thierry I, the count of Bar. ${ }^{57}$ Consequently, Austresius could actually have referred to either man, but Richard almost certainly meant Thierry I of Bar.

This argument is based upon the three following pieces of evidence. First, although both ducal functions were called 'dux Lothariensis' at that time, a text always referred to the duke in whose duchy the text was written, and Beaulieu was situated in the middle-west of Upper Lotharingia. ${ }^{58}$ Second, Godfrey II of Verdun was the first of his 'house' to obtain the ducal title of Lower Lotharingia in 1012, after the position had remained vacant for about seven years. ${ }^{59}$ The ducal title of Upper Lotharingia, in

\footnotetext{
${ }^{56}$ Matthias Werner, 'Der Herzog von Lothringen in salischer Zeit', in Die Salier und das Reich (see note 2), 375-6.

${ }^{57}$ Arlette Laret-Kayser, 'La fonction et les pouvoirs ducaux en Basse-Lotharingie au XI ${ }^{\mathrm{e}}$ siècle', Publications de la section historique de l'Institut Grand-Ducal de Luxembourg 95 (1981), 134-9; Poull, La maison, 17-9.

${ }^{58}$ Werner, 'Der Herzog', 377.

${ }^{59}$ Laret-Kayser, 'pouvoirs ducaux', 134-5.
} 
contrast, had been hereditarily passed on within the Bar family since $959 .^{60}$ Finally, during the first half of the eleventh century, 'Lotharingia' was practically synonymous with Upper Lotharingia. ${ }^{61}$

Therefore, the following hypothesis seems sustainable. Rather than inventing a conflict between Roding and a local nobleman named Austresius, Richard was actually describing a conflict between the community of Beaulieu and the neighbouring counts of Bar. That could explain this sentence in the Vita Rodingi: 'Is (Austresius) denique cum audisset homines barbaricae gentis (Roding and his fellow brethren) silvam quae iure hereditario a se possidebatur, introisse sibique in ea mansiunculas, precisis arboribus construere, mandavit eis dicens non esse equum aliena invadere'. ${ }^{62}$ Indeed, this seems to refer to Thierry I of Bar's claim that Beaulieu, as well as its surroundings, belonged to his hereditary possessions. In fact, several other elements in the Vita, especially Richard's choice of place names, seem to support this hypothesis.

The first place that appears in the text is Resson (Riessonnis), in chapter 8. This village is located merely $5 \mathrm{~km}$ east of Bar-le-Duc but $30 \mathrm{~km}$ south of Beaulieu. This is where Roding performed his first miracle, restoring a well and discovering a pound of gold in it. In the presence of many witnesses, Roding used the gold to buy the well from 'a certain elderly woman whose wealth would benefit from the sale of that well'. ${ }^{63}$ It is indeed obvious that this story was meant to confirm one of Beaulieu's possessions, albeit not the entire village of Resson, just a specific well located there.

In order to understand this story, a look at Resson's history proves illuminating. When he ceded the abbeys of Moyenmoutier and Saint-Dié to the bishop of Toul, Count Frederic I of Bar received several villages in return, including Resson. ${ }^{64}$ After his death in 978, his widow Beatrix sold Resson, as well as 58 other villages and mansi, to Bishop Gerard of Toul in c. 984 in exchange for the lifelong ownership of

${ }^{60}$ Eduard Hlawitschka, 'Die Sterbedaten der Herzöge von Oberlothringen', in Forschungsbeiträge der Geisterswissenschaftlichen Klasse, ed. Edward Hlawitschka (München, 2002), 69.

${ }^{61}$ Walter Mohr, Geschichte des Herzogtums Lothringen, vol. 1 (Saarbrücken, 1974), 51.

${ }^{62}$ Vita Rodingi, c. 6, 267-8.

${ }^{63}$ Ibid., c. 8-9; 269-70.

${ }^{64}$ Grosdidier de Matons, Le comté de Bar, 58. 
Moyenmoutier and Saint-Dié for herself and her son Thierry I. ${ }^{65}$ However, after she died in 1003, her son Thierry I of Bar managed to recover ownership of everything his mother had sold to the bishop of Toul in c. 984, including Resson. ${ }^{66}$

Consequently, Resson itself never belonged to Beaulieu. Apart from the bishop of Toul's brief ownership, it was part of the family patrimony of the house of Bar. If Beaulieu had indeed bought a certain well in Resson from the owner of this village, as Richard claimed, it must have happened through a sale by either the count of Bar or the bishop of Toul. Since the Vita clearly refers to an 'old woman' as the rightful owner of Resson, it seems safe to assume that Beaulieu had acquired this well from Beatrix sometime in the six years preceding 984 , when she was already in her forties. ${ }^{67}$ After all, between her husband's passing in 978 and Thierry I's coming of age in 985, Countess Beatrix of Bar acted as regent of her son, and thus as the rightful owner of all possessions of the Bar patrimony, including Resson. ${ }^{68}$ The fact that Richard felt the need to explicitly refer to Beaulieu's indisputable acquisition of this well - although in an allegorical manner - seems to indicate that Thierry I of Bar challenged its sale by his mother.

A similar argument can be made for the next place mentioned in the text, which is Hargeville (Argisivilla), situated $9 \mathrm{~km}$ north of Bar-le-Duc and c. $25 \mathrm{~km}$ south of Beaulieu. ${ }^{69}$ In chapter 10, Roding heals a certain widow, after which she donates her small estate of 'Argisivilla', including hereditary rights, to Roding. ${ }^{70}$ Haubrichs' identification of 'Argisivilla' as Auzéville, situated $9 \mathrm{~km}$ north of Beaulieu, is hardly tenable, either phonologically or historically. The church of Auzéville and its patrimony

${ }^{65}$ For an edition of the charter recording this exchange, see Picard, Histoire, 336-7. Although this charter is not dated, it is based upon a charter from 984 confirming the deceased Frederic of Bar's decision to cede Moyenmoutier and Saint-Dié to Gerard of Toul, see MGH, Diplomata Otto III (DD OIII), 395-6, nr. 2. Poull, La maison, 12-3.

${ }^{66}$ Gesta episcoporum Tullensium, ed. Waitz (MGH SS, 8, Hannover, 1848), c. 36, 642.

${ }^{67}$ For Beatrix's date of birth, see Robert Parisot, Les origines de la Haute-Lorraine et sa première maison ducale (959-1033) (Parijs, 1909), 296-8.

${ }^{68}$ Poull, La maison, 13-5.

${ }^{69}$ Félix Lienard, Dictionnaire topographique de la Meuse (Paris, 1872), 103.

${ }^{70}$ Vita Rodingi, c. 10, 271. 
actually belonged to the archdeacon of Argonne from the later eighth century until 1339. ${ }^{71}$ Rather, 'Argisivilla' refers to Hargeville-sur-Chée, as suggested by Wagner. ${ }^{72}$ Although sources remain silent on any previous ownership of this village, it was located within the regions controlled by the counts of Bar. It is not unthinkable that this village also previously belonged to Beatrix, either as part of her dowry or as one of the acquisitions of her deceased husband. By mentioning a donation by a widow, Richard might have been referring to a donation by Beatrix, widowed since 978 .

In the part of the Vita dealing with the local conflict, another place is mentioned: 'Bonna'. In chapter 12, immediately after Austresius' donation to Roding, the saint healed the nobleman's sister Bava, after which he received her property, called Bonna, to be held in perpetuity. ${ }^{73}$ However, the identification of 'Bonna' or 'Bava' proves more difficult than the previous two cases. Nevertheless, in analogy with the stories on Resson and Hargeville, we may expect a reference to lands previously owned by the Bar family, a suspicion reinforced by the explicit reference to Austresius' sister. Based upon present-day field names, Haubrichs proposed that 'Bonna' referred to a brook in Autrécourt, where once a small habitation might have existed. ${ }^{74}$ However, other historical records lack any reference to this place, nor does the Vita's chapter on Bonna make any reference to any brook or spring. When looking for other possibilities in Beaulieu's environment, the villages Bonnet and Boncourt might also come into consideration, situated respectively $40 \mathrm{~km}$ south-east of Bar-le-Duc and $9 \mathrm{~km}$ south of Saint-Mihiel, the most important monastic centre of the Bar family's patrimony. ${ }^{75}$ Nevertheless, neither of these options is really convincing. In addition, a great many of

${ }^{71}$ Longnon and Carrière, Pouillés, 368. Auzéville was called 'Algeivilla' in the eleventh century, see Lienard, Dictionnaire, 10.

${ }^{72}$ Wagner, 'Vie de Saint Rouin', 31 note 46. Called 'Hargevilla' in 1402, see Lienard, Dictionnaire, 103.

${ }^{73}$ Vita Rodingi, c. 12, 272.

${ }^{74}$ Haubrichs, Abtslisten, 100 note 443; Lienard, Dictionnaire, 29.

${ }^{75}$ For Bonnet: Lienard, Dictionnaire, 29. A charter from 982 tells how Bishop Gerard of Toul donated this village's church to Saint-Mansuy, but not the village itself, see Augustin Calmet, Histoire de Lorraine, vol. 2 (Nancy, 1745), CCXXXVII-LV. For Boncourt: Lienard, Dictionnaire, 28-9. On the importance of Saint-Mihiel to the Bar-family, see Poull, La maison, 19. 
the place names in the region where the Bar family had possessions contain a variant of the prefix 'bonne'. 76

Rather than focusing on 'Bonna', a solution might be found in the name of Austresius' sister, Bava. At first glance, this would seem to contradict the possibility that Thierry I of Bar can be identified as Austresius, as Thierry did not have a sister. Identifying Bava as Adela of Bar, Thierry's daughter, is also impossible due to her young age at the time of an eventual transaction. ${ }^{77}$ However, when looking at the villages sold by Beatrix to Gerard of Toul in c. 984, and recovered by Thierry I of Bar in the beginning of the eleventh century, 'Longamvillam', or Longeville, situated c. 6 $\mathrm{km}$ south-east of Bar-le-Duc and $4 \mathrm{~km}$ south of Resson, is explicitly named in the charter. ${ }^{78}$ A part of this village is called 'Bavat', meaning that this could very well be the place to which Richard was referring. ${ }^{79}$ In this case, Richard again used a personification to reveal the hidden meaning behind the miracle stories; Bonna could refer to the better part of this territory, and would have been understood by Richard's intended audience.

Summarizing, if the above reconstructions are correct, all three place names in the part of the Vita dealing with the conflict between Roding and Austresius refer to domains close to Bar-le-Duc. Two cases, Resson and Longeville, even concern villages which certainly belonged to Beatrix before 984, and to the count of Bar since the beginning of the eleventh century. All the more striking is that each one of the three miracle stories explicitly mentions a female person (an old woman, a widow, a sister) as the donor, reinforcing the hypothesis that Richard was referring to donations by Beatrix, mother of Thierry I of Bar, who thus might have been one of Beaulieu's benefactors in the tenth century. The fact that Richard clearly felt the need to devote a large part of his Vita Rodingi to assert Beaulieu's apparently legitimate and 'eternal' possession of these

\footnotetext{
${ }^{76}$ This area stretched from the northern-east of Verdun to the south of Bar-le-Duc, as well as the region around the monasteries of Moyenmoutier and Saint-Dié, see Poull, $\mathrm{La}$ maison, 7.

${ }^{77}$ Poull, La maison, 18-20. Although her date of birth is not known, her parents Thierry I of Bar and Richilde of Metz married around 985, which means that Adela was born after this year.

${ }^{78}$ Picard, Histoire, 336-7.

${ }^{79}$ Lienard, Dictionnaire, 18.
} 
three domains, hereby making use of the saint's authority, seems to indicate that their ownership was disputed at the time of the Vita's redaction. Even though hard evidence remains lacking, the geographic location of these villages, as well as the allegorical references to a conflict between the abbey and the count of Bar, leaves little doubt that Thierry I of Bar, or one of his family members, was contesting Beaulieu's rights in these places. ${ }^{80}$

It should be mentioned that one last place appears in the text, namely 'Ermeriacam'. After peace was made between Roding and Austresius, Beaulieu's prestige grew, and it received a papal charter and acquired some important relics. In order to secure these new possessions, Roding travelled to Childeric, king of the Franks from $662-673 / 75$, to receive a royal confirmation. ${ }^{81}$ At the king's court, the saint received 'Ermeriacam' from an unspecified lord, a donation confirmed by Childeric. The king subsequently placed the abbey under royal protection and granted it immunity from any external service. ${ }^{82}$ As mentioned above, Haubrichs identified 'Ermeriacam' as Evres, the central village of Beaulieu's domains. ${ }^{83}$ Although the name 'Ermeriacam' does not seem to correlate with 'Heberiaca', as Evres was called in 702, Haubrichs convincingly argued that this was caused by an aberration of the twelfth-century copyist of the Vita Rodingi. ${ }^{84}$ Consequently, Richard's mention of Evres does indeed seem to be meant as a reference to Beaulieu's most important property. Yet due to its position in the Vita a few chapters after the conflict with Austresius, there is no reason to assume that Beaulieu's possession of this place was also contested by the count of Bar.

\footnotetext{
${ }^{80}$ Even if the count of Bar considered some degree of control over this monastery (for example its advocacy) to be his by right of inheritance, his stance towards this monastery's possessions could still be very ambiguous.

${ }^{81}$ Vita Rodingi, c. 13-15, 272-4.

${ }^{82}$ Ibid., c. 16, 275.

${ }^{83}$ Haubrichs, 'Urkunde', 8-10.

${ }^{84}$ Haubrichs, 'Urkunde', 10-1. According to Haubrichs, the ' $b$ ' in the German word 'Heberiaca' evolved into a 'uu' after 702. The 'uu' of 'Euueriaca' was then wrongly copied around 1100 as 'rm', resulting in 'Ermeriaca'.
} 


\section{Integrating Local Reforms into a Regional Context}

Let us now turn to the question of what these identifications might reveal about Bishop Haimo's initiative to entrust Beaulieu into Richard's care. First, the overview of Beaulieu's geography has made clear that both the bishop of Verdun and the counts of Bar's wish to claim a certain degree of control over this institution was largely a result of it's strategic location. While the count of Bar might have invoked his hereditary rights in order to include Beaulieu as part of his family inheritance, the bishop of Verdun must have been very reticent about recognizing such a claim, as he also desired some authority over this institution. After all, the vast plains that the abbey overlooked constituted not only the borderlands between the counties of Bar and Verdun but also the borderlands between the bishoprics of Toul and Verdun. Given that the delineation of these borders was very unclear and highly disputed, it was undoubtedly the de facto situation that mattered most. Consequently, having an abbot of one's own choice elected likely also meant being able to use the site as a fortified outpost in order to exert a certain degree of control over the surrounding borderlands.

These findings shed a different light on Richard of Saint-Vanne's nomination in Beaulieu, which, due to his reputation as a reformer, has traditionally been explained as the result of a previous period of institutional decline. ${ }^{85}$ Although such a claim can be neither proven nor refuted due to a lack of sources, it seems that geopolitical motives were also at stake when Haimo nominated Richard. Hirschmann and Vanderputten have already explained how Bishop Dado of Verdun (880-923) used Beaulieu as a fortified outpost to defend his diocese against neighbouring rivals. ${ }^{86}$ When Bishop Haimo started to transform his diocese into a rich and powerful region a century later, he obviously

${ }^{85}$ The Vita Popponis claims that the monastery had fallen into ruin before Richard's arrival.

Everhelm, Vita Popponis abbatis Stabulensis, ed. D.W. Wattenbach (MGH, SS, 11, Hannover, 1854), c. 13, 301 [referred to hereafter as Vita Popponis].

${ }^{86}$ Hirschmann, 'L'abbaye', 15; Vanderputten, Imagining, 151. They used the expression 'aussenfort', which derives from Heinrich Fichtenau, “'Stadtplannung” im frühem Mittelalter', in Ethnogenese und Überlieferung, ed. Karl Brunner and Brigitte Mert (Vienna and München, 1994), 232-49. 
wished to retain a certain degree of control over this monastery. ${ }^{87}$ Thus Beaulieu had to be led by an abbot of his own choice, and Richard must have seemed the ideal candidate with both a profile as successful abbot and his history of cooperation with Bishop Haimo in particular. $^{88}$ Consequently, Richard's appointment in Beaulieu can be interpreted as a tactical move by Haimo to reinforce his grip over the abbey and thereby strengthen the episcopal sphere of influence in the south-western borderlands of his diocese.

The fact that many chapters of the Vita Rodingi have - albeit allegorically been devoted to quashing any proprietary claims of the count of Bar over certain of Beaulieu's properties supports the hypothesis that Richard's intervention was mainly aimed against the count of Bar. However, it is especially the story about how Astresius tried to evict Roding and his monks from the forests of Beaulieu, which he considered to be his by right of inheritance, that seems to have been inspired by this frontier dispute between the bishop of Verdun and the count of Bar. This should be read as a reference to the conflict between Thierry I of Bar and Richard of Saint-Vanne and his monks over the former's right to elect an abbot of his own choice by right of inheritance. Furthermore, another passage in the Vita Rodingi seems to encompass an implicit defence against Thierry I of Bar. This is hidden in chapter 16, and deals with King Childeric's granting immunity from any external service to Beaulieu. ${ }^{89}$ There, we can read the following: '[...] et ipsam abbatiam sua regia defensione munitam, ab omni prorsus externo servitio liberam et immunem esse constituit, reservato Virdunensium pontifici, cuius diocesi continetur, respectu sacrorum ordinum et benedictionis' ${ }^{90}$ Most interesting here is the remark that despite this royal protection and immunity, the bishop of Verdun maintained the rights to administer holy orders and, more importantly, to consecrate new abbots. ${ }^{91}$ Since this passage confirms rather than challenges Beaulieu's

${ }^{87}$ Hirschmann, Verdun, 315; Jean-Pol Evrard, 'Verdun, au temps de l'évêque Haymon (9881024)', in Religion et culture autour de l'an Mil, ed. Dominique Iogna-Prat and JeanCharles Picard (Paris, 1990), 276-7; Evrard, 'Les comtes', 167.

${ }^{88}$ Vanderputten, Imagining, 94-105.

${ }^{89}$ Vita Rodingi, c. 16, 275.

${ }^{90}$ Idem.

${ }^{91}$ Vita Rodingi, c. 16, 275. Vanderputten noticed that this passage is reminiscent of Bishop Haimo's (988-1024) politics, see Vanderputten, Imagining, 64. C. 3 and 4 of the Vita 
former status as a Western Frankish royal monastery, it implicitly recognizes the rights of the persons to whom this monastic protection was passed on over the centuries, in this case, arguably, the counts of Bar. However, Richard's need to explicitly mention the episcopal right of 'sacrorum ordinum et benedictionis', which includes the blessing - and approval - of the monastery's abbot, strongly suggests that this passage was primarily included in order to defend the episcopal right to exert a de facto control over Beaulieu's strategic location.

Nonetheless, while this local conflict might explain Richard's involvement in Beaulieu, why Richard left the monastery's daily management to his associate Poppo instead of taking up the task himself remains to be explained..$^{92}$ Due to his connection with Richard of Saint-Vanne, Poppo has traditionally been recognized as one of the main representatives of monastic reform in Lotharingia. His nomination in 1020 as abbot in Stavelot-Malmedy set Poppo's career on an impressive trajectory. In 1023, Emperor Henry II nominated him as abbot of the important Saint-Maximin abbey (Trier), and during the reign of Emperor Conrad II (1024-1039), Poppo became one of the most powerful abbots in the history of medieval German monasteries. No fewer than 27 Benedictine institutions, most of them located in Lotharingia, directly or indirectly came under his influence. ${ }^{93}$

Rodingi, which recount the close friendship between Roding and Bishop Paul of Verdun, must be considered from this perspective.

${ }^{92}$ Following the Vita Popponis' internal chronology, this happened in 1015/16, between Poppo's appearance at the imperial court in Nijmegen as Saint-Vaast's prior in 1015 and his attendance at the imperial court in Strasbourg in 1016 as Beaulieu's prior. Vita Popponis, c. 12-4, 300-2. For the dating of the Nijmegen imperial court, see Bloch, 'Urkunden, vol. II', 419-24. For the dating of the Strasbourg meeting in 1016, see Paul Ladewig, Poppo von Stablo und die Klosterreformen unter den ersten Saliern (Berlijn, 1883), 36 note 3. Schäfer and Krauss erroneously assumed that Poppo had been abbot in Beaulieu, although Poppo's Vita clearly states that Richard made Poppo 'second' in this place. See Vita Popponis, c. 13, 301; Schäfer, Studien, 34-5; Sabine Krauss, 'Christi iugum leve sub monastica institutione ipsis iniecit', in Flores considerationum amicorum, ed. Wolfgang Hasberg and Josef Schröder (Gleichen, 2006), 291.

${ }^{93}$ In Lotharingia: Beaulieu, Bouzonville, Brauweiler, Echternach, Hautmont, Mouzon, St Agerich, St Ghislain, St Laurent, St Truiden, Stavelot-Malmedy, St-Eucharius, St- 
However, when he became prior of Beaulieu, Poppo, at that time 37/38 years old, was still at the very beginning of his monastic career. ${ }^{94}$ Born in Flanders, he had only converted to the monastic life in his later 20 s, after having served the count of Holland as miles. In the subsequent decade, he had been a monk in Saint-Thierry (Reims, c. 1005/08-1008), Saint-Vanne (Verdun, 1008-1012/13), and prior in SaintVaast (Arras, 1012/13-1015/16). ${ }^{95}$ Therefore using Poppo's reputation as a competent administrator to explain his nomination in Beaulieu derives mainly from a post-hoc perspective. Moreover, the hypothesis that Richard's intervention in Beaulieu was essentially politically motivated makes Richard's choice to leave the abbey's care in Poppo's hands all the more remarkable. After all, Richard's other associate, Frederic of Verdun, seems at first glance more suited for this task. Being the son of Count Godfrey I of Verdun, Frederic undeniably possessed more local social capital and was much more familiar with the region. ${ }^{96}$

In order to understand Poppo's nomination, we must shift our focus away from the local and consider the wider political context. Indeed, we are referring to the more

Martin (Trier), St-Maximin, St-Vincent (Metz), Waulsort-Hastière. In Francia: Fulda, Hersfeld, Limburg, Weissenburg. In Saxonia: Bergen, Nienburg. In Alemania: St-Gallen. In Flanders: Marchiennes, St-Vaast. In France: St-Martin (Laon). In Frisia: Hohorst. Poppo's influence on these institutions will be discussed thoroughly in my doctoral dissertation, to be completed by the end of 2015. On Poppo, see also Paul Ladewig, Poppo von Stablo und die Klosterreformen unter den ersten Saliern (Berlijn, 1883); Henri Glaesener, 'Saint Poppon, abbé de Stavelot-Malmédy', Revue Bénédictine 60 (1950), 16379; Schäfer, Studien; Christian Schmidtmann, 'Poppo von Stablo: Sein Abbatiat in St. Maximin vor dem Hintergrund der Klosterreformbewegung des 10./11. Jahrhunderts', Landeskundliche Vierteljahresblätter 42 (1996), 69-82; Philippe George, 'Un réformateur lotharingien de choc: l'abbé Poppon de Stavelot (978-1048)', Revue Mabillon 71 (1999), 89-111; Krauss, 'Christi iugum', 281-314.

${ }^{94}$ Poppo's Vita mentions his death at the age of 70 in 1048, making 978 his year of birth. Vita

Popponis, c. 28, 312-3. Also Annales Stabulenses, ed. Waitz (MGH, SS, 13, Hannover, 1881), 43.

${ }^{95}$ Poppo's early career is discussed more thoroughly in my upcoming article, Koen Vanheule,

'The beginnings of a monastic reformer' (working paper, Ghent, 2015).

${ }^{96}$ Instead, Frederic of Verdun became Saint-Vaast's prior until his death in 1022, see

Vanderputten, Monastic Reform, 90. 
than ten-year rebellion of the Luxembourg brothers, mentioned in the introduction. The usurpation of Metz's episcopal see in 1005-1006 by Thierry of Luxembourg (called Thierry II of Metz in the following) from his minor nephew Adalbero of Bar was a forerunner of this conflict. ${ }^{97}$ After Thierry II of Metz's protest against the imperial donation of Kunigunde's dowry to Bamberg in 1007, and after his brother Adalbero of Luxembourg (called Adalbero of Trier in the following) had feigned imperial consent to occupy the episcopal see of Trier in 1008, Emperor Henry II could no longer stand idly by ${ }^{98}$ Supported by the count of Bar, the emperor dispatched his army to the cities of Trier and Metz, albeit without success. ${ }^{99}$ In the meantime, the four Luxembourg brothers (Count Frederic of Luxembourg, Adalbero of Trier, Thierry II of Metz and Henry V, who was deposed as duke of Bavaria in 1009) received support from their

${ }^{97}$ Parisot, les origines, 383-95. According to Sigebert of Gemboux, this usurpation happened in 1009 , although it seems that he was confused in his chronology. See Sigebert of Gembloux, Chronica, ed. Ludwig C. Bethmann (MGH, SS, 6, Hannover, 1844), a. 1009, 354; also Arnaud Hari, 'Ecrire l'histoire des évêques de Metz au Moyen Age' (PhD diss., Université de Lorraine, 2010), 162-3; Frank G. Hirsch, Hermann Pabst and Harry Bresslau, Jahrbücher des Deutschen Reichs unter Heinrich, vol. 1 (Berlin, 1862), 360-1.

Twellenkamp, 'Luxemburger', 480. This also marked the end of the cohesion between both families, which had remained strong in the later tenth century, when their fathers were alive, see for example Henri H. Jongbloed, 'Wanburtich: Heinrichs II. Beteiligung an der Wahl von Kamba (1024)', Deutches Archiv für die Erforschung des Mittelalters 62 (2006), 32-3.

${ }^{98}$ Heinz Wolter, Die Synoden im Reichsgebiet und in Reichsitalien von 916 bis 1056 (Paderborn, 1988), 243-4.

${ }^{99}$ The most important source for this conflict is Thietmar of Merseburg's chronicle, book 6, chapters 52, 53, 60, 74, and book 7, chapters 9, 26, 54, 62, 66, 67. Here: Thietmar of Merseburg, Chronicon, ed. Robert Holtzmann (MGH, SS rerum Germanicarum, Nova Series, 9, Berlin, 1935), book 6, c. 53, 340 [referred to hereafter as Chronicon Thietmari]; Hermann of Reichenau, Chronicon de sex aetatibus mundi, ed. Georg Heinrich Pertz (MGH, SS, 5, Hannover, 1844), a. 1008, 119 [referred to hereafter as Chronicon Herimanni]. Also Franz-Reiner Erkens, 'Fürstliche Opposition in ottonisch-salischer Zeit', Archiv für Kulturgeschichte 64 (1982), 349-52; Camille Wampach, Urkunden- und Quellenbuch zur Geschichte der altluxemburgischen Territorien, vol. 1 (Luxemburg, 1935), 312. 
brother-in-law Gerard, the count of Metz, and from Ezzo, the count palatine of Lotharingia. In 1011, this conflict reached its apotheosis. Returning from Mainz, Thierry I of Bar, together with Bishops Haimo of Verdun and Berthold of Toul, ran into an ambush. ${ }^{100}$ Wounded, Thierry I of Bar was only left alive by the Luxembourg insurgents because 'he had [formerly] been their friend'. ${ }^{101}$ While Thierry II of Metz also sought papal support, the emperor ravaged Upper Lotharingia twice and organized no fewer than three synods against the rebels in $1012 .{ }^{102}$ It was probably on one of these occasions that Henry II nominated Godfrey II of Verdun as duke of Lower Lotharingia, making him a stronger ally in that region. ${ }^{103}$ [Figure 2 near here]

Starting in 1015, the year of Richard's appointment in Beaulieu, the tide was turning for the Lotharingian insurgents. Not only had Godfrey II of Verdun defeated his long-time opponent Lambert of Louvain, meaning that he could now concentrate on the Upper Lotharingian rebels, but also Trier's imperial anti-bishop Megingaud had died. ${ }^{104}$ Bishop Haimo of Verdun played a key role in the election of Poppo of Babenberg as Trier's new bishop, after which Adalbero of Trier had to capitulate - a first defeat for the Luxembourg family. ${ }^{105}$ It was not until 1017 that Henry II made peace with the Luxembourg brothers, after which Godfrey II of Verdun's troops finally defeated both

100 The imperial court had gathered in Mainz to condemn the Luxembourg rebellion.

${ }^{101}$ Chronicon Thietmari, book 6, c. 52, 340. Also Chronicon Herimanni, a. 1011, 119; Annales Quedlinburgenses, ed. Martina Giese (MGH, SS rer. Germ., 72, Hannover, 2004), 532; Annales Brunwilarenses, ed. Georg Heinrich Pertz (MGH, SS, 16, Hannover, 1859), 132. See also Hirsch, Jahrbücher, vol. 2, 309-11.

102 Wolter, Die Synoden, 245-51; Chronicon Thietmari, book 6, c. 60, 348, c. 74, 364; Annales Altahenses maiores, ed. Edmund Oefele (MGH, SS rer. Germ., 4, Hannover, 1891), a. $1012,17$.

${ }^{103}$ Wolter, Die Synoden, 245-51. This probably happened at the synod in Koblenz, November 1012, with bishops Gerard of Cambrai and Balderic of Liège as notable attendants.

${ }^{104}$ Hirsch, Jahrbücher, vol. 3, 26. Godfrey II of Verdun also had a history of conflict with the rebel Gerard of Metz, see Léon Vanderkindere, La formation territoriale des principautés Belges au Moyen Age, vol. 2 (Brussel, 1902), 29.

105 Chronicon Thietmari, book 7, c. 26, 430-1; Twellenkamp, 'Luxemburger', 483. 
them and Gerard of Metz. ${ }^{106}$ Yet while swords thereafter remained in their scabbards, regional tensions between the Luxembourg family and the counts of Bar and Verdun remained. ${ }^{107}$ This became clear once more during Conrad II's election as new king, in 1024, when the Luxembourg brothers again found themselves opposed to the counts of Bar and Verdun. ${ }^{108}$

Due to its somewhat isolated location in the Argonne, the small abbey of Beaulieu probably suffered little from these consecutive campaigns. Nonetheless, this regional context enables us to understand Poppo's appointment. If Bishop Haimo's nomination of Richard was indeed politically motivated, the bishop needed a strong leader in order to resist the Bar family's claims. As stated, Richard of Saint-Vanne must have seemed the ideal candidate for this task due to his previous reputation as a monastic leader, his history of reliable cooperation with Haimo in Saint-Vanne and his ability to deal with politically sensitive challenges. ${ }^{109}$ Nonetheless, Richard's close relationship with the Verdun family, who needed the support of the Bar family in their struggle against the count of Metz and the Luxembourgers, might have prevented Richard from taking too staunch a position against the counts of Bar. ${ }^{110}$ This must have been the case especially in 1015, when Saint-Vanne received Mouzon's toll and minting rights from Herman of Ename, the count of Verdun's brother. ${ }^{111}$ Of course, this further explains why Richard's other collaborator, Frederic of Verdun, who had been the count of Verdun himself until 1005, seemed less suited to governing Beaulieu. ${ }^{112}$

Poppo, in contrast, had the perfect profile to meet the episcopal demands. Recent research has demonstrated how Poppo's early career was strongly shaped by the

${ }^{106}$ Chronicon Thietmari, book 7, c. 54, 466, c. 62, 475, c. 66, 480, book 8, c. 17, 515. Also

Hirsch, Pabst and Bresslau, Jahrbucher, vol. 3, 26; Vanderkindere, La Formation, vol.

2, 29. In this battle, the future Emperor Conrad II fought on the side of Luxembourg.

${ }^{107}$ Chronicon Thietmari, book 8, c. 34, 532.

108 Poull, La maison, 22.

${ }^{109}$ Vanderputten, Imagining, 96-9; Vanderputten, Monastic Reform, 83-90.

${ }^{110}$ Vanderputten, Imagining, 99-105.

${ }^{111}$ MGH, Diplomata Heinrich II (DD HII), 431-5, nr. 340; also Vanderputten, Imagining, 99.

112 Jongbloed, 'Wanburtich', 31-3. 
evolving interests of the Luxembourg family. ${ }^{113}$ A direct family tie is not demonstrable, but Poppo had served Lutgard of Luxembourg before his monastic entrance, a link that proved to be determinative for his subsequent life. ${ }^{114}$ His conversion in Saint-Thierry and transfer to Saint-Vanne, both pre-1008, happened when the Luxembourgers were still allied with the Verdun family, who were trying to gain more influence in Reims. Poppo's nomination in Saint-Vaast in Flanders happened shortly after Baldwin IV, the count of Flanders, had ended his struggle with the emperor and had married Frederic of Luxembourg's daughter Ogive. ${ }^{115}$ However, the importance of Poppo's contacts with the Luxembourg family became most apparent later, with his nomination as abbot in Stavelot-Malmedy, in 1020; shortly thereafter, Count Frederic of Luxembourg became the abbey's first high advocate. ${ }^{116}$ A more or less similar situation prevailed under Poppo's leadership in Saint-Maximin, and also in many of his other institutions, where the influence of the Luxembourg family is clearly discernible. ${ }^{117}$ Stating that Poppo was a monastic leader in this family's service may be a bridge too far, yet it is clear that, at least in the eyes of contemporaries, his identity was inextricably linked with the interests of the Luxembourg brothers and sisters. Since the Luxembourg family was involved in the regional warfare against the Bar family during the time of Poppo's nomination in Beaulieu, his selection may have been an effort to exploit his contacts with this family.

${ }^{113}$ Vanheule, 'The beginnings'.

${ }^{114}$ Vanheule, 'The beginnings'. Poppo had served the minor Count of Holland Thierry III as a miles, with the latter's mother, Lutgard of Luxembourg, as Thierry's regent.

${ }^{115}$ On the conflict between Baldwin IV and Henry II, and Saint-Vaast's role therein, see Van Meter, 'Count Baldwin', 139-47. The exact year of Baldwin's marriage with Ogive of Luxembourg is not known, although it is assumed that this happened in the aftermath of the peace process. However, some authors, such as Ganshof and Renn, have assumed that Baldwin IV was already engaged to Ogive before 1006. François Louis Ganshof, 'Les origines de la Flandre impériale', Annales de la société d'archéologie de Bruxelles 46 (1942-1943), 108; Renn, 'Luxemburger', 115-6; Erich Brandenburg, Die Nachkommen Karls des Grossen: 1.-14. Generation (Leipzig, 1935), 96, nr. 51.

${ }^{116}$ Vanheule, 'The beginnings'. Poppo's nomination also happened at a time when the family of Luxembourg was trying to re-establish their influence over this institution.

${ }^{117}$ This will be discussed in my doctoral dissertation, to be completed by the end of 2015 . 
Despite his close contacts with the Luxembourg family, Poppo also maintained good relations with the Verdun family and with the bishop of Verdun, which is illustrated by his collaboration with Richard in Saint-Vanne, as well as by his close friendship with Frederic of Verdun. ${ }^{118}$ This was possible due to Poppo's rather peripheral position within the Luxembourg network, which made his role as an 'interlock' between these two families easier to maintain. ${ }^{119}$ Therefore, Poppo was an ideal compromise candidate for Beaulieu's leadership. Acceptable to the bishop and the leading elites of Verdun, Poppo also possessed the social capital requisite for successfully challenging the count of Bar's claim over Beaulieu and some of its possessions. In short, Richard skilfully made use of the regional dispute between the brothers of the Luxembourg family and the count of Bar to choose the most appropriate candidate amongst his monks to transpose this regional struggle to the local level of Beaulieu in order to safeguard Verdun's episcopal interests.

In this respect, it is interesting to mention that both the change of name from 'Waslogium' to 'Bellus Locus' (or 'Beloacum', which evolved into 'Beaulieu') and the construction of new buildings in Beaulieu are accredited to Poppo's management, at least according to the Vita Popponis. ${ }^{120}$ Both can be considered unambiguous symbols of appropriation, meant to increasingly exclude the Bar family from the institution's historical identity. Equally noteworthy is Poppo's appearance at the imperial court in Strasbourg, shortly after his appointment in Beaulieu. ${ }^{121}$ This happened only a few months after Adalbero of Luxembourg's resignation as bishop of Trier, and thus in the middle of the peace process between the Luxembourg brothers and Emperor Henry

\footnotetext{
118 Vita Popponis, c.10, 299, c. 11, 300.

119 'Interlock' is a term used in social network analysis, denominating persons connecting different 'core groups' in networks, see William K. Carroll and J.P. Sapinski, 'Corporate Elites and Intercorporate Networks', in The Sage Handbook of Social Network Analysis, ed. John Scott and Peter J. Carrington (London, 2011), 180-95.

${ }^{120}$ Vita Popponis, c. 13, 301. This change of name is also mentioned in the Vita Rodingi, although Poppo is not mentioned. Vita Rodingi, c. 4, 266.

121 Vita Popponis, c. 13-14, 301-2. This happened in 1016, see note 92 above.
} 
II. ${ }^{122}$ Possibly, Poppo went to plead Beaulieu's case with the emperor, although he might also have been involved in these regional negotiations as a mediator for the Luxembourgers.

As a last remark, chapters 13 and 14 of the Vita Rodingi also include some hints about how Richard and Poppo tried to change Beaulieu's identity in order to re-orient the institution even further towards episcopal control. In chapter 14, Richard tells the story of how Roding, returning from Rome, reached the monastery of Saint-Maurice in the Alps. Burning with desire to acquire one of Mauritius' relics, he bribed the monastery's provost with a large sum of money so that he could open the grave, steal a bone from the saints' elbow and then flee into the night. ${ }^{123}$ In the previous chapter of the Vita Rodingi, Richard told how Roding had built his monastery in honour of St Mauritius, and so gaining one of the saint's relics was indeed a meaningful mission for Roding. ${ }^{124}$ However, Mauritius' remains were nearly impossible to obtain. ${ }^{125}$ According to several historians who refer to Richard's special interest in relics and their cults, the story of the theft thus served to legitimize Beaulieu's presumed possession of one of Mauritius' bones. ${ }^{126}$ However, the Vita does not mention any miracle performed by this relic, and therefore neglects to demonstrate the saint's powers, which is a conditio sine qua non of attracting pilgrims. ${ }^{127}$

${ }^{122}$ Chronicon Thietmari, book 7, c. 29, 431-2. It was also on this occasion that Rudolf of Burgundy swore allegiance to Henry II. The dukes of Upper and Lower Lotharingia undoubtedly must have been present at such an important event.

${ }^{123}$ Vita Rodingi, c. 14, 273.

${ }^{124}$ Vita Rodingi, c. 13, 272.

${ }^{125}$ Anne Wagner, 'Le culte des martyrs de la Légion Thébaine dans l'Empire ottonien', in Autour de Saint Maurice, ed. Nicole Brocard (Saint-Maurice, 2012), 406-8.

${ }^{126}$ Hirschmann, 'L'abbaye', 20-1; Wagner, 'Vie de Saint Rouin', 33-4; Vanderputten, Imagining, 63-4. According to Geary, Richard 'saw nothing contradictory or immoral about his theft or falsification of important relics'. Patrick Geary, Furta Sacra (Princeton, 1978), 79. Although Geary does not mention Roding's theft of Mauritius' relic, he refers to Richard's illicit acquisition of St Sanctinus' relics, see ibid., 78-89.

${ }^{127}$ This has also been remarked upon by Wagner, 'Vie de Saint Rouin', 34 note 57. 
In fact, it seems that this story served not so much to confirm Beaulieu's relic treasury as to firmly link Beaulieu to the imperial sphere of influence. ${ }^{128}$ After all, St Mauritius was not 'just' one of the numerous martyrs venerated by the Church; he was the patron of the Ottonian dynasty and of the German empire, and his relics represented the imperial power. ${ }^{129}$ This becomes all the more interesting when looking at the earliest mentions of St Mauritius being Beaulieu's patron saint. The first indication that Beaulieu was linked to St Mauritius postdates Richard's appointment in Beaulieu, appearing for the first time in a charter from 1025, where Beaulieu is called 'sancti Mauricii'. ${ }^{130}$ From then on, this name was frequently used. ${ }^{131}$ This suggests that St Mauritius' role as Beaulieu's patron saint only started during Richard's leadership. ${ }^{132}$ By placing the abbey under Mauritius' protection, Richard could strengthen its Eastern

${ }^{128}$ Vanderputten has already noted that St Mauritius was of particular significance to Henry II, as well as to Bishop Haimo. See Vanderputten, Imagining, 84 note 55, 170-1 note 56.

${ }^{129}$ Wagner, 'Culte', 406-8, 417. Mauritius became the empire's patron during the reign of Henry I, who bought Mauritius' lance, sword and spurs from the king of Burgundy. Mauritius remained one of the patrons of the German empire until the twentieth century, and his sword and spurs were part of the royal insignia. See also Maurice Zufferey, 'Der Mauritiuskult im Früh- und Hochmittelalter', Historisches Jahrbuch 106 (1986), 23-58; David A. Warner, 'The cult of Saint Maurice' (PhD diss., University of California, 1989). ${ }^{130}$ MGH, Diplomata Konrad II (DD KII), 45, nr. 40. Before 1000, the abbey's former name, 'Wasloi' (870) or 'Waslogium' (916-925), was always used to designate the abbey. See Annales de Saint-Bertin, 174; Gesta, ed. Waitz, c. 9, 43, c. 13, 44. One exception is Pepin Herstal's charter from 702, which does mention 'Sancti Mauritii' (or 'Moricii'). However, Haubrichs demonstrated that the names in this charter had been modernized by a twelthcentury copyist to their then-current variants. See Bloch, 'Urkunden, vol. II', 377-8; Haubrichs, 'Urkunde', 1, 7.

${ }^{131}$ For example, Laurent of Liège, Gesta episcoporum Virdunensium et abbatum S. Vitoni, ed. Giorgio Waitz (MGH, SS, 10, Hannover, 1852), 491; and Lemaire, Recherches, 177-8.

132 The earliest proof that Beaulieu possessed relics of St Mauritius dates from the nineteenth century, see Nicolas Roussel, Histoire ecclésiastique et civile de Verdun, second edition (Bar-le-Duc, 1863-1864), 197. 
Frankish profile, thereby increasingly disassociating it from its Western Frankish history and - more importantly - from the hereditary claims of the family of Bar. ${ }^{133}$

\section{The Attenuated Dissemination of the Vita Rodingi}

A confrontation between Beaulieu's history and geography, the regional political context of the time and the analysis of the Vita Rodingi's allegorically hidden contents has led us towards a better understanding of Richard and Poppo's involvement in the abbey. However, the question still remains as to why Richard put so much effort into the redaction of a Vita, which from a post-hoc perspective never knew any dissemination to speak of. After all, only one copy of the original version has been preserved, written around 1100 in the monastery of Saint-Pierre-aux-Monts in Châlons, also one of Richard's institutions. ${ }^{134}$ In order to answer this question, we must first recover the time-frame of the original Vita's redaction.

Whereas most historians have dated the writing of the Vita Rodingi to within the rather rough time-span between Richard's nomination in Beaulieu in 1015 and his death in 1046, Vanderputten has suggested narrowing this down from c. 1024 until the early 1030s. ${ }^{135}$ His terminus post quem is based upon the redaction of the Vita Magnerici, written c. 1024 by Eberwin of Tholey. ${ }^{136}$ Richard, who maintained close contacts with Eberwin, seems to have used this text as an inspiration. ${ }^{137}$ It was also during those years

133 This hypothesis is reinforced by the fact that both references to St Mauritius in the Vita Rodingi are made directly after the chapter where Austresius cedes his rights over the forest around Beaulieu.

${ }^{134}$ See note 10 above. Also Haubrichs, Abtslisten, 98. Somewhere towards the end of the Middle Ages, the Vita Rodingi underwent a complete makeover, although this younger text only vaguely resembles Richard's original version. Many elements, such as the naming of the villages, the theft of Mauritius' relics and the royal charter, were left out, and the focus was more on Roding's virtues and his relationship with Tholey. It has been edited in Hugo Menard, Martyrologium sanctorum ordinis divi Benedicti (Paris, 1629), 690-5. See also Haubrichs, Abtslisten, 98 note 426; Wagner, 'Vie de Saint Rouin', 24 note 11 , notes 57 and 58 .

${ }^{135}$ Vanderputten, Imagining, 69-70.

${ }^{136}$ Haubrichs, Abtslisten, 164-7.

${ }^{137}$ Vanderputten, Imagining, 67-8. 
that Richard developed his self-conception as abbot and his ideas on eremitism, which are reflected in Roding's depiction. ${ }^{138}$ When Richard went on pilgrimage to Palestine in the autumn of 1026, together with Eberwin, he met Simeon of Syracuse, about whom Eberwin wrote a Vita in 1036. Since this text seemingly was not used as inspiration for the Vita Rodingi, 1036 could be considered a terminus ante quem. ${ }^{139}$

This time-span can be narrowed even further, by placing the Vita's redaction in 1026, shortly before Richard left on pilgrimage to Palestine. The years 1026/1027 would prove decisive for the Bar family's dynastic situation. On 18 May 1026, Frederic II, son and heir of the Count of Bar Thierry I, died. ${ }^{140}$ This echoes a short passage in the Vita, which relates that Austresius lost his children as a heavenly punishment, which could be read as a reference to the death of Thierry I's son. ${ }^{141}$ The passing of Frederic II left Thierry I, who was already a little over 50 years old, with only his daughter Adèle, married to the count of Arles, and his grandson Frederic III, just ten years old at that time. ${ }^{142}$ Yet while Adèle and Frederic III were not likely to pose any imminent threat to Beaulieu's possessions while Richard went to Palestine, Thierry I could still maintain his claims. Therefore, it is my hypothesis that Richard wrote the Vita Rodingi after Frederic II's passing, but shortly before he left for the Holy Land near the end of 1026. This way, Richard could arm the community with an easily understandable refutation of Thierry I of Bar's proprietary claims during his protracted absence and in case he did not return. ${ }^{143}$ Moreover, if Thierry I of Bar subsequently died and Frederic III were to

${ }^{138}$ Poull, La maison, 70-3.

${ }^{139}$ Ibid., 70; Haubrichs, Abtslisten, 167-8.

${ }^{140}$ His only other son, Adalbero, died before 1015, see parisot, Les origines, p. 371.

${ }^{141}$ Vita Rodingi, c. 7, 268.

${ }^{142}$ Poull, La maison, 20, 24.

${ }^{143}$ On the functionality of hagiographic texts in a context of conflict, see Jeroen Deploige, 'Twisten via heiligen. Hagiografische dialogen tussen de Gentse abdijen van Sint-Pieters en Sint-Baafs, 941-1079', Handelingen van de Maatschappij voor Geschiedenis en Oudheidkunde van Gent 31 (2007), 31-82. While redacting the Vita Rodingi, Richard also used this text to legitimize his pilgrimage by expounding his ideas on abbatial leadership. In the Vita Rodingi, physical wandering is depicted as serving the goal of spiritual withdrawal from the secular world, and thus not as a breach of the ideal of stability. See Vanderputten, Imagining, 70-2; Helena Vanommeslaeghe, 'Wandering Abbots. Abbatial 
continue his grandfather's dispute with the abbey after coming of age, the Vita Rodingi could be used as textual confirmation of Beaulieu's possessions.

The course of history partly confirmed Richard's expectations, for by the time he returned in 1027, the count of Bar had died at the age of 55. ${ }^{144}$ However, what no one could foresee was that in 1033 Frederic III of Bar would also die, just one year after he came of age. ${ }^{145}$ This marked the end of Bar's male family line, and it was Frederic III's sister Beatrix who inherited the regions around Beaulieu. Being married to Bonifacio of Canossa, she did not invest much energy in her Lotharingian possessions; she spent the greater part of her life in Italy, a situation that did not change after her second marriage to Count Godfrey III of Verdun. ${ }^{146}$ If one of the objectives of the Vita Rodingi was to counter claims of the Bar family to some of Beaulieu's possessions and affirm Verdun's episcopal de facto control over its strategic location, this means that the text already lost some of its direct and short-term relevance in 1027 - shortly after its creation. This caused the loss of the meaning behind the allegorical story of Austresius and thus its erasure from the community's collective memory in the following decades. As a consequence, Roding's life story degenerated into a typical foundation story with no further relevance, especially after the count of Bar officially acquired Beaulieu around 1170. ${ }^{147}$ This, in turn, explains the text's limited distribution.

Finally, what can the dating of the Vita Rodingi reveal about Richard's motivations for its redaction? After all, if our dating is correct, it was written a little more than ten years after Richard's nomination in Beaulieu, and six years after Poppo left the Argonne for Stavelot-Malmedy. This means that the text was written a few years after the battle between the Luxembourg and Bar families, and the conflict between the count of Bar and the bishop of Verdun. Since several passages contain traces of reconciliation, I would like to suggest that Richard considered this text a form of

Mobility and stabilitas loci in Eleventh-Century Lotharingia and Flanders', in Medieval

Liège at the Crossroads of Europe, ed. Steven Vanderputten, Tjamke Snijders and Jay

Diehl (Turnhout, forthcoming).

144 Thierry I died on 11 April 1017.

${ }^{145}$ Poull, la maison, 24.

${ }^{146}$ Ibid., 38-42.

${ }^{147}$ See note 41 above. In turn, this also explains the lack of interest in certain passages in the

Vita's later remake, see note 134 above. 
closure. Of special interest is chapter 11 of the Vita, in which Austresius confessed his crimes against Roding and conferred on the latter eternal ownership over the forests around Beaulieu. ${ }^{148}$ This suggests that the count of Bar had abandoned his struggle for control over the abbey's strategic location and accepted episcopal control over the abbatial elections. In turn, Richard acknowledged Bar's hereditary rights over Beaulieu when he endorsed the institution's history as a Western Frankish royal monastery in chapter $16 .{ }^{149}$ This seems to indicate that by the time of the Vita's redaction, some sort of local equilibrium had been reached. While the bishop of Verdun maintained his de facto control over his southern borders by having an abbot of his choice elected, the count of Bar was recognized as the abbey's advocate.

\section{Conclusion}

Until now, the tenth- and eleventh-century history of Beaulieu has remained a blind spot within our knowledge of high medieval monastic institutions. Likewise Richard and Poppo's intervention in this abbey has been commonly accepted as 'monastic reform' due to their reputations. However, a collation of the institution's history and geography, the identification of the Vita Rodingi's hidden layers and the regional political context at that time have made it possible to formulate some well-grounded hypotheses on these 'lost histories'. Richard's decision to mention specific characters, names and places, as well as to position them within certain parts of the text, was by no means arbitrary. Quite the contrary: he drew inspiration from the institution's local political context, which rendered the story of Austresius understandable for all parties involved, even though it remained encrypted enough to transcend the level of an ordinary chronicle. This way, it would not inhibit the promotion of Roding's local cult, which undeniably remained Richard's primary objective in redacting the Vita. However, Roding's life story was more than just a reflection of Beaulieu's recent history, as Richard also intended this text as a means to communicate Beaulieu's political environment. On the one hand, it served as a closure of a local conflict which reflected the regional balances of power, while on the other, it could act as a lieu de mémoire for the small community in case the family of Bar pressed its claims to some of Beaulieu's domains. As a

\footnotetext{
${ }^{148}$ Vita Rodingi, c. 11-12, 271-2.

${ }^{149}$ Vita Rodingi, c. 16, 275.
} 
consequence, the Vita Rodingi is able to offer us some insight into Richard's involvement in Beaulieu, which has to be framed within a context of conflicting interests between the bishop of Verdun and the count of Bar, each claiming some degree of control over Beaulieu's strategic position within the borderland. Furthermore, Richard's text also demonstrates how certain short-term evolutions within monasteries, often too quickly considered monastic 'reforms', could actually have been motivated by concrete political goals. ${ }^{150}$ These goals become fully understandable only when integrating these local histories into their short-term regional contexts. Given the fluid nature of high medieval politics with its constantly changing actors and shifting alliances, texts such as the Vita Rodingi could quickly be deprived of their allegorically hidden histories, degenerating into seemingly trivial and topical saint's stories.

\section{Acknowledgements}

This article was written in the context of the research project 'Monastic leadership in the postcharismatic age: Constructing a new paradigm for the study of reforms before the emergence of the great Orders (Western Europe, tenth-early twelfth centuries)', sponsored by the Flemish Research Foundation (FWO). I would like to express my thanks to Steven Vanderputten for his remarks and for lending me a draft of his recently published book Imagining Religious Leadership in the Middle Ages: Richard of Saint-Vanne and the Politics of Reform (Ithaca, NY, 2015).

${ }^{150}$ See also Vanderputten, Monastic reform, 79-130, 186-9. See note 4 above. 




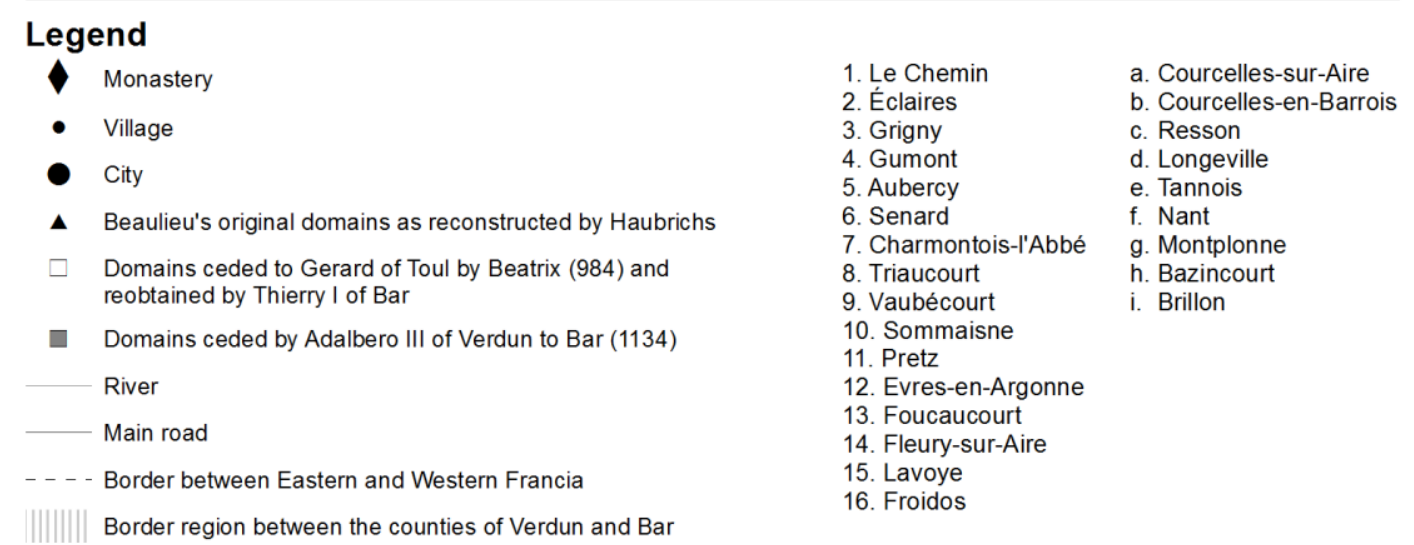

Figure 1. Map of Beaulieu and its surroundings. 


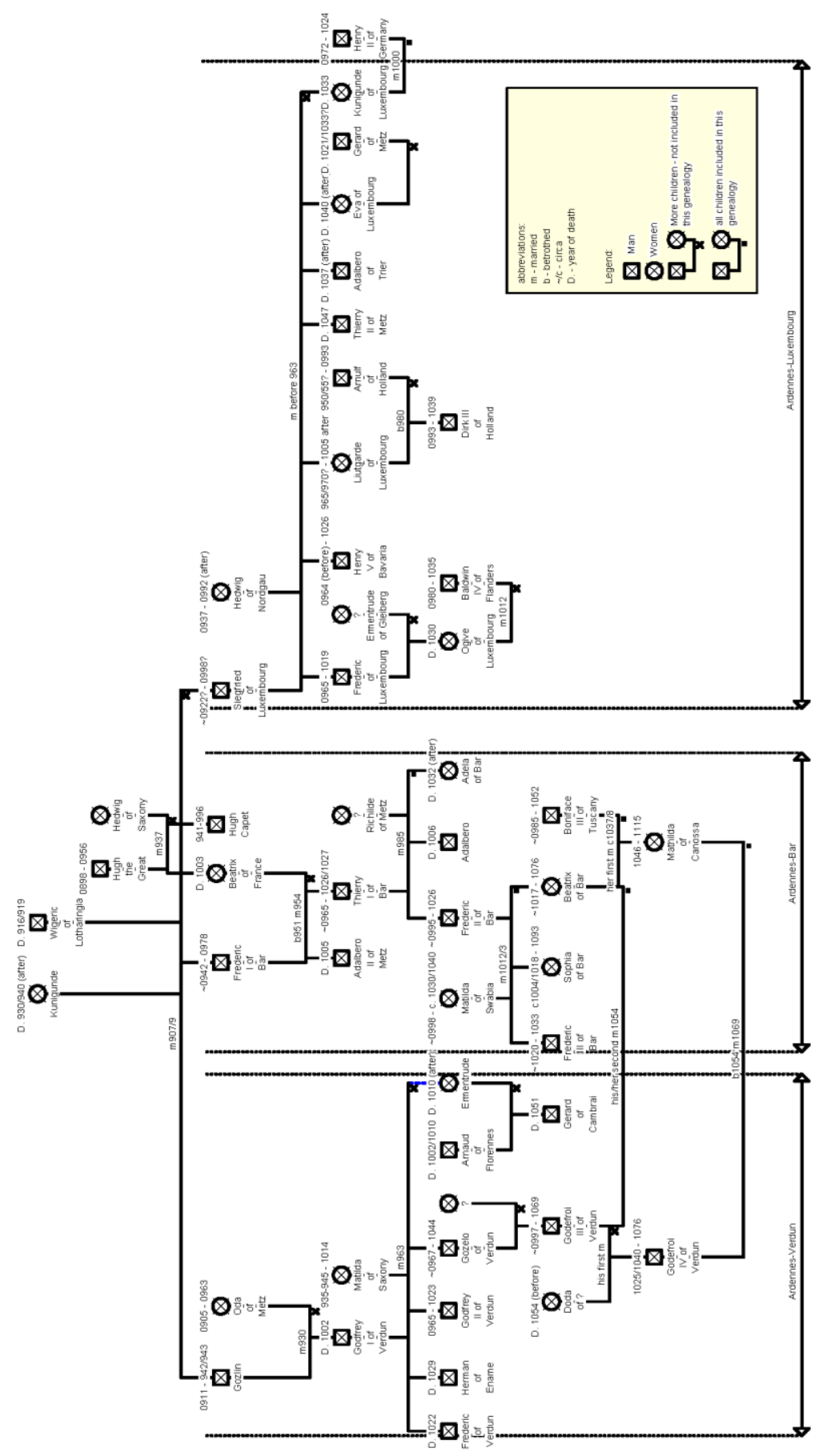

Figure 2. Descendants of Wigeric. This genealogy is by no means exhaustive, as only the persons mentioned explicitly in the article, and their partners, are included. 